\title{
KHOTBAH EKSPOSISI NARASI YANG KREATIF DAN KONTEKSTUAL BAGI ANAK-ANAK GENERASI Z USIA 5-6 TAHUN
}

\author{
Oleh: \\ ${ }^{* 1}$ Kezia Yemima dan ${ }^{* 2}$ Sarah Stefani \\ ${ }^{* 1}$ Dosen Sekolah Tinggi Teologi Gamaliel Surakarta \\ ${ }^{*}$ Mahasiswa Program Magister Teologi Sekolah Tinggi Teologi Gamaliel Surakarta \\ Email : \\ ${ }^{* 1}$ kezia_y@ hotmail.com, *2 greace.stefani@gmail.com
}

\begin{abstract}
ABSTRAK-Gereja memiliki tugas untuk membina setiap warga gerejanya. Sekolah Minggu merupakan program pembinaan warga gereja bagi anak-anak untuk mengenalkan mereka kepada Tuhan Yesus. Salah satu cara untuk mengenalkan anak-anak kepada Tuhan Yesus adalah khotbah eksposisi narasi. Anak-anak yang dilayani yaitu para generasi $Z$ yang berusia 5-6 tahun. Tujuan dari penelitian ini adalah untuk menemukan cara khotbah eksposisi narasi yang kreatif dan kontekstual bagi anak-anak generasi Z usia 5-6 tahun. Penelitian ini menggunakan teknik penelitian kualitatif dengan metode hermeneutika teks Alkitab dan studi literatur. Hasil dari penelitian ini adalah khotbah eksposisi narasi kreatif dan kontekstual bagi anak-anak generasi Z usia 5-6 tahun. Metode khotbah ini merupakan metode khotbah yang isinya didasarkan pada proses hermeneutika yang benar dan disampaikan secara kreatif serta kontekstual sesuai dengan karakteristik dan kebutuhan anak.
\end{abstract}

Kata kunci: Khotbah Eksposisi Narasi, Generasi Z, Anak 5-6 tahun.

ABSTRACT-The church has the duty to foster every citizen of his church include the childrens. Sekolah minggu is the program of the church to foster every child. The way to introduce children to the Lord Jesus is a narrative exposition preaching. The children served are the gen $Z$ aged 5-6 years. The aim of this research is to find a creative and contextual narrative exposition preaching to gen $Z$ aged 5-6 years. This research uses qualitative research techniques with biblical text hermeneutics methods and literature studies. The result of this research is creative and contextual narrative exposition preaching to gen $Z$ aged 5-6 years. The method of preaching is a preaching whose content is based on correct hermeneutics method and delivered creatively and contextually according to the characteristics and needs of the child.

Keywords: Narative Exposition Preaching, Creative, Contextual, Gen Z

\section{LATAR BELAKANG MASALAH}

Sekolah Minggu adalah suatu bentuk pelayanan pembinaan warga gereja terhadap anak-anak. Tujuannya untuk mengenalkan mereka kepada Yesus, hingga mereka menerima-Nya sebagai Tuhan dan
Juruselamatnya secara pribadi. $^{1}$ Tugas utama seorang guru sekolah minggu adalah mengenalkan anak kepada Tuhan Yesus. Salah satu bentuk pelayanan sekolah minggu ialah khotbah. Khotbah eksposisi 
adalah salah satu metode berkhotbah untuk memperkenalkan anak kepada Tuhan Yesus.

Pada kenyataannya, terdapat kesulitan dalam mengkhotbahkan Tuhan Yesus jika teks khotbah berasal dari Perjanjian Lama. Pengkhotbah terjebak dalam kisah tokoh yang diceritakan sehingga amanat teks yang dihasilkan berupa etika kehidupan saja. ${ }^{2}$ Tantangan lain ialah gab komunikasi antara guru sekolah minggu dan anak-anak masa kini oleh karena perbedaan generasi. Anakanak masa kini, yang disebut juga dengan generasi $\mathrm{Z}$ adalah anak-anak yang melek teknologi, memiliki daya konsentrasi yang rendah namun dapat menangkap informasi dengan cepat, media audiovisual menjadi sumber belajar dan anak-anak mulai kurang menyukai model pembelajaran auditory learning seperti ceramah dan diskusi. ${ }^{3}$ Bagi mereka cerita alkitab merupakan hal yang jarang didengar, padahal dari cerita alkitab tersebut mereka dapat menemukan kebenaran sejati yaitu Tuhan Yesus. Oleh karena itu perlu melakukan penelitian untuk menemukan metode khotbah yang sesuai dengan kebutuhan dan karakteristik anakanak generasi $\mathrm{Z}$ usia 5-6 tahun dalam rangka membawa mereka mengenal dan menerima Tuhan Yesus.

\section{RUMUSAN MASALAH}

Bagaimana khotbah eksposisi narasi yang kreatif dan kontekstual bagi anak-anak generasi $\mathrm{Z}$ usia 5-6 tahun?

${ }^{2}$ Sidney Greidanus, Preaching Christ From The Old Testament, (Bandung: Kalam Hidup, 2009), 64.

${ }^{3}$ Darla Rothman, A tsunami og learners called Gen Z, Mdle, Spring, Vol 1, Issue 1, 2014, 3-4

\section{TUJUAN DAN MANFAAT PENELITIAN}

Menemukan cara berkhotbah eksposisi narasi yang kreatif dan kontekstual bagi anak-anak generasi $\mathrm{Z}$ usia 5-6 tahun. Manfaat penelitian yaitu memberi masukan teoritis dan praktis bagi guru-guru sekolah minggu di gereja-gereja untuk menggunakan khotbah ekspositori narasi secara kreatif dan kontektual dalam mengajarkan Yesus Kristus dari teks Perjanjian Lama kepada anak-anak generazi $\mathrm{Z}$ usia 5-6 tahun.

\section{METODE PENELITIAN}

Penelitian ini menggunakan teknik peneletian kualitatif dengan metode hermeneutika/eksegesa teks Alkitab dan studi literatur.

\section{HASIL PENELITIAN \\ Khotbah Eksposisi Narasi}

Benny Solihin mengartikan khotbah eksposisi narasi adalah khotbah yang mengkomunikasikan suatu konsep Alkitabiah dari teks narasi, dihasilkan dan disampaikan melalui penyelidikan historis, gramatikal, dan kesusastraan suatu teks dalam konteksnya, di mana Roh Kudus menerapkan hal itu dalam hidup pengkhotbah dan kemudian diterapkan dalam hidup pendengar. ${ }^{4}$ Sidney Greidanus mengartikan khotbah eksposisi sebagai khotbah Kristosentris yang berarti suatu metode khotbah menafsirkan Perjanjian Lama yang berusaha mengapresiasi fakta tentang Allah ynag membawa kerajaanNya ke

${ }^{4}$ Benny Solihin, 7 Langkah Khotbah yang mengubah kehidupan, (Malang: Literatur SAAT, 2014), 18 
bumi dan berpusat pada Kristus. ${ }^{5}$ Dalam penelitian ini, khotbah eksposisi narasi adalah khotbah yang disampaikan berdasarkan proses penyelidikan yang benar sesuai dengan konteks teks narasi dan berpusat pada pemberitaan tentang keselamatan dalam Yesus. Dalam khotbah eksposisi narasi terdapat 3 aspek utama yang dilihat yaitu pengkhotbah, isi khotbah dan cara komunikasi, sebagaimana dipaparkan berikut:

\section{Pengkhotbah}

Terdapat 3 karakteristik utama pengkhotbah yaitu karaktestik rohani, karakteristik kepribadian, dan karakteristik kompetensi. Pertama, karakteristik rohani. Karakteristik rohani yang harus dimililiki oleh pengkhotbah adalah orang yang bergantung kepada kuasa Roh Kudus dan berhikmat, orang yang lahir baru, orang yang mencintai Firman Tuhan dan memberikan waktu untuk menyelidiki kebenaran Firman Tuhan, memiliki kerinduan untuk menjangkau dan memuridkan anak-anak, serta memiliki motivasi untuk berkhotbah Kristosentris.

Menurut Kisah Para Rasul 6:3-10, saat Stefanus ditunjuk oleh para Rasul untuk membantu pelayanan mereka. Karakteristik rohani yang ditunjukkan adalah orang yang dipenuhi Roh Kudus, penuh iman, berhikmat, dan memiliki kerelaan hati untuk melayani. Menurut Yohanes 6:1-13, karakteristik pengkhotbah yang ditunjukkan Tuhan Yesus meliputi karakteristik rohani

${ }^{5}$ Sidney Greidanus, Preaching Christ From The Old Testament, 323 ialah orang yang diurapi dan hadir dengan kuasa. Benny Solihin mengungkapkan hal pertama yang harus diperhatikan dalam khotbah eksposisi adalah kesadaran pengkhotbah untuk bergantung pada pimpinan Roh Kudus. ${ }^{6}$ Alasan pentingnya pengkhotbah harus bergantung kepada Roh Kudus, yaitu pertama, khotbah adalah kreasi Allah. ${ }^{7}$ Kedua, hanya kuasa Roh Kuduslah yang dapat mengubah manusia. ${ }^{8}$ Ketiga, khotbah adalah unsur pelayanan gereja yang paling berdampak dalam kehidupan seseorang. ${ }^{9}$

Sidney Greidanus menyatakan bahwa tanggung jawab utama seorang pengkhotbah adalah berusaha memahami perikop yang dipilih dalam konteks sejarah-budayanya sendiri. ${ }^{10}$ Memahami pesan teks dalam konteks kanon dan sejarah penebusan. ${ }^{11}$ Pengkhotbah memahami kebutuhan konteks pendengar masa kini. ${ }^{12}$ Dalam proses ini, pengkhotbah harus bersandar penuh kepada Roh Kudus sebagai kontrol dari penafsiran Alkitab yang dilakukan oleh pengkhotbah.

Menurut Superbook, sebuah kurikulum yang dapat digunakan untuk sekolah minggu yang berbasis film animasi. Superbook sendiri mulai masuk dan ditayangkan di Indonesia

${ }^{6}$ Benny Solihin, 7 Langkah Khotbah yang mengubah kehidupan, 33.

${ }^{7}$ Ibid. 34.

${ }^{8}$ Ibid, 35.

${ }^{9}$ Mary S. Hulst, Pedoman Khotbah Lengkap, (Jakarta: Waskita, 2018), 21.

${ }^{10}$ Sidney Greidanus, Preaching Christ From The Old Testament, 324.

${ }^{11}$ Ibid. 410.

${ }^{12}$ Ibid, 417. 
tahun 2013. ${ }^{13}$ Karakteristik rohani bagi pengkhotbah Superbook adalah orang yang mau bersama menjangkau dan memuridkan anak-anak. ${ }^{14}$ Superbook memiliki tujuan untuk menjangkau dan memuridkan anak-anak, oleh karena itu pengkhotbah Superbook pun harus memiliki tujuan yang sama. Menurut Be Kids, sebuah kurikulum pelayanan anak yang dikembangkan oleh Gereja Bethel Indonesia. Saat ini Be Kids telah berubah nama menjadi kingdom kids dibawah pembinaan dari Departemen Pemuda dan Anak Gereja Bethel Indonesia. ${ }^{15}$ Karakteristik rohani pengkhotbah sekolah minggu adalah orang yang diurapi Roh Kudus dan dipakai Allah untuk berkhotbah dihadapan anak-anak sehingga anakanak bisa bertobat dan menerima Tuhan Yesus sebagai Tuhan dan Juruselamatnya secara pribadi.

Kedua, karakteristik kepribadian. Menurut tinjauan Kisah Para Rasus 6:17:60 dan Yohanes 6:1-13 Kualifikasi kepribadian pengkhotbah meliputi memiliki kesaksian hidup yang baik, mengasihi, memperhatikan dan melayani kebutuhan pendengar yaitu anak-anak yang dilayani. MenKualifikasi kepribadian pengkhotbah meliputi mengasihi pendengar, menyediakan waktu untuk mengenal pendengar dan memiliki kesaksian hidup yang baik. Kualifikasi kompetensi pengkhotbah meliputi

\footnotetext{
14“'Seminar Pelatihan Superbook", (Caruban,: 4 Mei 2018).

${ }^{15} \mathrm{http}: / / \mathrm{www}$. dpagbi. org/sites/index.php/berita-utama/60-rakernas-i2018/588-kepu-tusan-rakernas-i-2018
}

${ }^{13}$ www.superbookindonesia.com, diakses 27 November 2018 memiliki pengetahuan Alkitab untuk melakukan proses penafsiran Alkitab yang benar, cakap dalam menyusun relevansi khotbah dengan kehidupan pendengar, memahami konteks pendengar, isi khotbah Alkitabiah dan mampu menyampaikannya secara manarik dan aplikatif.

Ketiga, karakteristik kompetensi. Karakteristik kompetensi pengkhotbah yaitu, pertama, Tinjauan Kisah Para Rasus 6:1-7:60 dan Yohanes 6:1-13. Kualifikasi kompetensi pengkhotbah meliputi: menguasai pengetahuan tentang Alkitab, mampu memberikan penjelasan secara runtut, mampu merelevansikan kebenaran Alkitab dengan konteks pendengar, dan mampu menyampaikan khotbah sesuai dengan karakter dan kebutuhan pendengar.

Kedua, Tinjauan para ahli yaitu Benny Solihin, Sidney Greidanus, Super Book dan Be Kids. Menurut para ahli kualifikasi, kompetensi pengkhotbah meliputi memiliki pengetahuan Alkitab untuk melakukan proses penafsiran Alkitab yang benar, cakap dalam menyusun relevansi khotbah dengan kehidupan pendengar, memahami konteks pendengar, isi khotbah Alkitabiah dan mampu menyampaikannya secara manarik dan aplikatif.

\section{Isi khotbah.}

Menurut tinjauan Kisah Para Rasus 6:1-7:60 dan Yohanes 6:1-13 isi khotbah eksposisi yang baik ialah kontekstual, berpusat pada pemberitaan berita keselamatan melalui Tuhan Yesus, menyatakan pribadi 
Allah, sesuai dengan kebutuhan pendengar, dan membawa pendengar untuk menerima Tuhan Yesus secara pribadi. Menurut tinjauan para ahli, isi khotbah eksposisi haruslah berpusat kepada Kristus, menyatakan kebenaran, didasarkan pada proses penafsiran yang benar dan objektif, terlihat gambaran teks dari sudut pandang sejarah penebusan dan penyataan Tuhan Yesus melalui teks yang dipilih, relevan dan aplikatif bagi kehidupan pendengar.

Tinjauan metode khotbah anak masa kini oleh Superbook dan Be Kids. Menurut Superbook, isi khotbah membawa anak-anak kepada kebenaran, melihat sejarah Alkitab, dan menghubungkan kisah yang diceritakan dengan Kristus. Menurut Be Kids isi khotbah adalah pemberitaan tentang Tuhan Yesus supaya anak-anak menerima Tuhan Yesus secara pribadi.

\section{Cara komunikasi}

Menurut tinjauan Kisah Para Rasus 6:1-7:60 dan Yohanes 6:1-13 cara komunikasi yang efektif adalah menyampaikan Firman Tuhan dengan demonstrasi kuasa, dimana pendengar dapat melihat secara langsung karya Tuhan. Khotbah harus disampaikan secara berani, percaya diri, jelas, tegas, dan memperhatikan karakteristik dan kebutuhan pendengar. Menurut tinjauan para ahli, cara komunikasi khotbah memiliki tiga kunci utama yaitu relevan, menarik, dan aplikatif dalam kehidupan pendengar.

Tinjauan metode khotbah anak masa kini oleh superbook dan be kids. Menurut superbook, cara komunikasi khotbah anak-anak masa kini adalah menggunakan media audio visual, penjelasan pengkhotbah, dan permainan interaktif. Menurut be kids, cara komunikasi khotbah adalah bercerita dengan gerak tubuh, gambar atau alat peraga, dan suara.

\section{Pengenalan Pelayanan Anak-Anak Di Sekolah Minggu}

Sekolah minggu adalah suatu bentuk pembinaan warga gereja yang ditujukan untuk anak-anak. ${ }^{16}$ Sekolah minggu merupakan pelayanan yang sangat erat kaitannya dengan gereja. Pada intinya bentuk pelayanan dari sekolah minggu ini adalah anak-anak dikumpulkan dan diajar Firman Tuhan pada hari Minggu dan kegiatan ini dilaksanakan oleh Gereja. ${ }^{17}$ Prioritas utamanya gereja adalah penyelamatan orang yang terhilang dan pembangunan tubuh Kristus. ${ }^{18}$ Artinya gereja harus membuat pendengar mengerti akan kebenaran dengan berbagai cara. Jika pendengar tersebut adalah anak-anak maka injil harus disampaikan dengan cara sedemikian rupa agar anak-anak mengerti dan menyerahkan dirinya kepada Tuhan Yesus. Berdasarkan sistem Westhill, rentang usia anak-anak yang dilayani dalam sekolah minggu adalah 0-14 tahun, artinya anak-anak usia 5-6 tahun masuk kedalam kategori usia yang dilayani dalam sekolah

\footnotetext{
${ }^{16} \mathrm{Br}$ Ginting, Peranan Guru Sekolah Minggu dalam Proses Pengajaran di Sekolah Minggu, (epository.uksw.edu), 2013, 5-6.

${ }^{17}$ Ruth Laufer \& Anni Dyck, Pedoman Pelayanan Anak, (Surabaya: Bahtera, 2014), 34

${ }^{18}$ Richard L, Penginjilan di Sekolah Minggu, (USA: The Gospel Publishing House, 1983), 7. 
minggu. ${ }^{19}$ Tiga aturan pokok dalam sistem ini adalah mempelajari seluruh aspek perkembangan anak, guru bekerja dan mengembangkan potensi anak, dan menyusun tata ibadah yang sesuai dengan anak. ${ }^{20}$

Perkembangan zaman saat ini pada akhirnya juga memberikan pengaruh terhadap gereja, yang artinya juga berpengaruh pada Sekolah Minggu. Anak-anak usia lima sampai enam tahun yang dilayani Sekolah Minggu saat ini sangat jauh berbeda dengan anak-anak usia lima sampai enam tahun yang dilayani sekolah minggu dua puluh atau tiga puluh tahun yang lalu. Pengamatan terhadap anakanak sekolah minggu di GBI Ngawi menunjukkan bahwa anak-anak sangat antusias terhadap teknologi seperti smartphone dan komputer. Hampir semua anak memiliki smartphone yang sebagian besar berbasis Android dan yang lainnya berbasis IOs. Rata-rata anak di kelas besar (8-12 tahun) memiliki akun whatsapp dan instagram pribadi serta menggunakannya secara aktif. Selain itu mereka juga merupakan pemain aktif dalam game online. Anak-anak di kelas kecil (1-6 tahun) rata-rata menggunakan smartphone untuk bermain game. Namun, untuk anak yang berusia 4-6 tahun ternyata mereka sudah akrab dengan fitur-fitur kamera yang ada di Instagram.

Dalam pembelajaran, mereka lebih antusias terhadap khotbahkhotbah yang disampaikan dengan menggunakan media audiovisual.

$$
\begin{aligned}
& { }^{19} \text { Ibid. } \\
& { }^{20} \text { Ibid. }
\end{aligned}
$$

Khotbah menggunakan media audiovisual lebih mudah dimengerti oleh mereka. Mereka lebih antusias untuk mendengarkan khotbah ketika guru menunjukkan gambar menggunakan IPad, handphone, dan laptop dibandingkan dengan gambar cetak. Berdasarkan hasil pengamatan ini, dapat disimpulkan bahwa saat ini sekolah minggu melayani anak-anak yang melek teknologi dan teknologi merupakan suatu kebutuhan bagi mereka.

Jika pada sistem Westhil ditekankan bahwa pelayanan di Sekolah Minggu harus berpusat pada anak atau memperhatikan kebutuhan anak. Maka, sekolah minggu saat ini juga harus menyesuaikan karakteristik dan kebutuhan anak-anak usia lima sampai enam tahun masa kini.

\section{Anak-Anak Usia 5-6 Tahun Dalam Kajian Teologis}

Anak-anak merupakan pribadi yang multidimensional, memiliki beberapa aspek dalam kehidupannya yaitu emosi, rohani, mental, kehendak dan jasmani. Kebutuhan anak ialah terpenuhinya seluruh kebutuhan setiap aspek kehidupannya. ${ }^{21}$ Secara rohani anak-anak memiliki status sebagai orang yang berdosa. ${ }^{22}$ Kebutuhan utama orang berdosa adalah keselematan. Tuhan Yesus sangat memperhatikan kebutuhan rohani anakanak. Matius 19:13-15 menunjukkan bahwa anak-anak memiliki tempat

\footnotetext{
${ }^{21}$ B.S Sidjabat, Membesarkan Anak Dengan Kreatif, (Yogyakarta: Andi, 2012), 150

${ }^{22}$ T. Yuliati, Penginjilan Anak (Bahan Ajar), (Surakarta: STT Gamaliel, 2014)
} 
dihati Tuhan Yesus. Anak-anak disini dalam bahasa Yunani menggunakan kata Paidon, yang berarti anak-anak kategori infant. ${ }^{23}$ Infant adalah anakanak usia 0-2 tahun. ${ }^{24}$ Ketika para murid menghalangi para orang tua yang datang kepada Tuhan Yesus untuk meminta penumpangan tangan dan doa, Tuhan Yesus melakukan hal sebaliknya. Tuhan Yesus menerima mereka dan memberikan penumpangan tangan serta mendoakan mereka. Peristiwa ini menunjukkan bahwa anakanak memiliki suatu pengalaman bersama dengan Tuhan. Pengalaman menerima Tuhan Yesus dan proses pendidikan rohani akan menolong anak melewati tahapan-tahapan perkembangan moral anak. ${ }^{25}$

\section{Anak-Anak Usia 5-6 Dalam Kajian} Teori Psikologi Perkembangan Anak

Berdasarkan perkembangan kognitif, anak memasuki tahap pemikiran praoperasional. Karakteristik utama dari tahap ini adalah munculnya system lambang dan simbol. Anak mulai merepresentasikan dunia dengan kata-kata dan gambar-gambar. ${ }^{26}$ Perkembangan persepsi anak didasarkan kepada kemampuan penglihatan anak dan tampilan visual yang dilihat oleh anak. ${ }^{27}$ Informasi-

\footnotetext{
${ }^{23} \mathrm{https} / / / w w w . b i b l e s t u d y t o o l s . c o m / l e x i c o n s /$ greek/nas/paidion.html

${ }^{24}$ https: //en. wikipedia. org/wiki/Child_development, diakses 6 Februari 2019

${ }^{25}$ Judith Allen Shelly, Kebutuhan Rohani Anak, (Bandung: Yayasan Kalam Hidup, 2003), 22.

${ }^{26}$ Desmita, Psikologi Perkembangan Anak, (Bandung: PT Remaja Rosdakarya, 2010), 47.

${ }^{27}$ Ibid, 134.
}

informasi dalam bentuk gambar mudah diterima dan masuk kedalam memori anak.

Dalam perkembangan bahasa pada sisi proses penerimaan bahasa, anak-anak usia 5-6 tahun memiliki kemampuan untuk menyimak perkataan orang lain, mengerti dua perintah yang diberikan bersamaan, memahami cerita yang dibacakan, anak mampu mengulang kalimat yang kompleks, dan dapat memahami aturan. ${ }^{28}$ Sedangkan dalam hal mengungkapkan bahasa, anak-anak usia 5-6 tahun mampu untuk mengulangi kalimatkalimat sederhana, menjawab pertanyaan sederhana, mengungkapkan perasaan, mengutarakan pendapat kepada orang lain, mengutarakan alasan terhadap sesuatu yang diinginkan dan ketidaksetujuannya, mampu menceritakan kembali cerita atau dongeng yang pernah didengarnya serta dapat melanjutkan cerita tersebut dan mampu menyusun kalimat secara lengkap. ${ }^{29}$

Dalam perkembangan psikososial, anak usia 5-6 tahun memasuki tahapan prakarsa dan rasa bersalah atau initiative versus guilt. Pada tahap ini, anak-anak terlihat sangat aktif dalam kegiatan fisik seperti berlari, memanjat, berkelahi, dan menantang lingkungan. Anak-anak akan menggunakan bahasa, fantasi dan permainan khayalan untuk memperoleh harga dirinya. Bermain merupakan kegiatan inti dalam kehidupan anak

${ }^{28}$ Permendiknas tentang Pendidikan Anak Usia Dini, Nomor 137 tahun 2014, 12.

${ }^{29}$ Ibid, 13. 
usia 5-6 tahun. $^{30}$ Bermain dan permainan menjadi sebuah proses yang berarti dalam tahap ini. Bermain dan permainan akan membantu anak dalam membangun kehidupan sosialnya dan memahami lingkungannya.

Dalam perkembangan fisik motorik, pada usia 5-6 tahun keterampilan-keterampilan motorik kasar dan motorik halus mengalami peningkatan yang pesat. Anak mampu untuk melakukan permainan fisik dengan aturan, melakukan eksplorasi dengan berbagai media dan kegiatan, dan mengekspresiakan diri melalui gerakan. ${ }^{31}$

Dalam perkembangan moral anak usia 5-6 tahun, kebenaran ditentukan oleh kata hari sesuati dengan prinsipprinsip etika universal yang bersifat abstrak dan penghormatan terhadap martabat manusia. ${ }^{32}$ Penggunaan kata hati sebagai acuan tindakan pada akhirnya merujuk kepada nilai-nilai keagamaan yang diberikan kepada anak. Hal ini berkaitan dengan kepercayaan yang dianut oleh orang tua. Nilai-nilai kepercayaan yang dianut oleh orang tua berpengaruh kepada nilai-nilai yang diajarkan kepada anak. ${ }^{33}$

Pencapaian perkembangan seni anak usia 5-6 tahun dalam lingkup perkembangan seni yang kedua ialah anak memilih lagu yang disukai, bernyanyi sendiri, menggunakan

44.

${ }^{30}$ Desmita, Psikologi Perkembangan Anak,

${ }^{31}$ Permendiknas, tentang Pendidikan Anak Usia Dini, 10-11.

${ }^{32}$ Desmita, Psikologi Perkembangan Anak, 152.

33 B. S Sidjabat, Membesarkan Anak Dengan Kreatif, 135. imajinasi untuk mencerminkan perasaan dalam sebuah peran, membedakan peran fantasi dan kenyataan, menggunakan dialog perilaku dan berbagai materi dalam menceritakan suatu cerita, mengekspresikan gerakan dengan irama yang bervariasi, menggambar objek disekitarnya, membentuk berdasarkan objek yang dilihatnya, menyanyikan lagu dengan sikap yang benar, menggunakan berbagai macam alat music untuk menirkan suatu irama atau lagu tertentu, bermain drama sederhana, melukis dengan berbagai cara dan objek, dan membuat karya seperti bentuk sesungguhnya dengan berbagai bahan. ${ }^{34}$

Anak-anak usia 5-6 tahun dalam teori generasi

Menurut Kupperschmidt's, generasi adalah sekelompok individu yang mengidentifikasi kelompoknya atas dasar kesamaan tahun kelahiran, umur, lokasi dan kejadian-kejadian dalam kehidupan kelompok tersebut yang berpengaruh signifikan dalam kehidupan mereka. Kemudian Howe dan Strauss, membagi generasi berdasarkan rentang waktu kelahiran dan kesamaan kejadian historis yang dialami, yang kemudian diikuti dan dikembangkan juga oleh penelitipeneliti yang lain. ${ }^{35}$ Generasi $\mathrm{Z}$ adalah generasi yang lahir pada tahun 20002025. ${ }^{36}$ Saat ini, generasi $\mathrm{Z}$ berusia 6-

\footnotetext{
${ }^{34}$ Permendinas tentang Pendidikan Anak Usia Dini, 10-12.

${ }^{35}$ Yanuar Surya Putra. Theoretical reviews: Teori Perbedaan Generasi, Jurnal Among Mikarti, Vol 9, No18, 2016, 7-8.

${ }^{36}$ Yelana Thomas dan $\mathrm{R}$ Srinivasan. Emerging Shifts in Learning Paradigms-From
} 
23 tahun. Generasi Z ini merupakan generasi pertama yang lahir di era internet. ${ }^{37}$ Artinya anak-anak usia 5-6 tahun saat ini masuk kedalam kategori generasi Z. Perubahan IPTEK telah mengakibat suatu perbedaan karakteristik yang mendalam antara anak-anak usia 5-6 tahun saat ini dengan anak-anak terdahulu.

Karakteristik anak-anak usia 5-6 tahun saat ini adalah sebagai berikut pertama, , memahami teknologi. ${ }^{38}$ Anak-anak masa kini adalah anak-anak yang sudah mengenal dan menggunakan teknologi diusia yang masih muda. Mereka bertumbuh bersamaan dengan perkembangan teknologi, smartphone dan berinteraksi dengan layar touchscreen. ${ }^{39}$ Kedua, Kedua, pengguna sosial media dan internet yang aktif. ${ }^{40}$ Google dan Youtube menjadi sumber belajar. Ketiga, Ketiga, perubahan struktur otak. Oleh karena penggunaan teknologi yang akif, otak anak-anak terhubung dengan citra visual yang rumit dan canggih, hal ini mengakibatkan bagian otak yang bertanggung jawab atas kemampuan visual berkembangan dengan sangat pesat. $^{41}$ Sehingga, anak lebih mudah menerima dan memahami informasi

Millenials to the Digital Natives. International Journal of Applied Engineering Research, Vol 11, Num 5, 2016, 4-5.

${ }^{37}$ Darla Rothman, A tsunami og learners called Gen Z, Mdle, Spring, Vol 1, Issue 1, 2014, 2-3.

${ }^{38}$ Ibid., 3-4

${ }^{39}$ Ádám Nagy - Attila Kölcsey, Generation Alpha: Marketing or Science?, Acta Technologica Dubnicae, vol. 7, issue 1, 2017, 4-5.

${ }^{40}$ Darla Rothman, A tsunami og learners called Gen Z, 3.

${ }^{41}$ Ibid dengan media visual. Keempat, memiliki rentang perhatian yang lebih pendek dibandingkan dengan generasi yang sebelumnya. ${ }^{42}$ Kelima, multitasking atau fast switcher. Multitasking merupakan kemampuan dasar dari anak-anak masa kini. ${ }^{43}$ Anak-anak dapat dengan mudah berpindah dari satu kegiatan ke kegiatan yang lain. Anak-anak dapat membaca, berbicara, melihat sesuatu, dan mendengarkan musik dalam waktu yang bersamaan. ${ }^{44}$

Kebutuhan dan gaya belajar anakanak generasi $\mathrm{Z}$ adalah sebagai berikut pertama, teknologi merupakan dasar dari pembelajaran. Penggunaan teknologi merupakan sebuah nature atau pembawaan tingkah laku anakanak masa kini. ${ }^{45}$ Pembelajaran yang berbasis teknologi dan multimedia interaktif menjadi sangat diminati oleh anak-anak. $^{46}$ Contohnya seperti penggunaan laptop, presentasi, dan perangkat-perangkat audiovisual.

Kedua, pembelajaran visual dan media interaktif. Perubahan struktur otak anak-anak akibat penggunaan teknologi dimana otak anak terhubung dengan citra visual yang canggih sehingga bagian otak anak yang mengontrol kemampuan visual anak

\footnotetext{
${ }^{42}$ Darla Rothman, A tsunami og learners called Gen Z, 4.

${ }^{43}$ Ádám Nagy - Attila Kölcsey, Generation Alpha: Marketing or Science?, Acta Technologica Dubnicae, vol. 7, issue 1, 2017, 5.

${ }^{44}$ Slameto, Generation $Z$ and the Implication for Counseling, (Salatiga: Universitas Satya Wacana Press, 2015), 6.

${ }^{45}$ Yelana Thomas dan $\mathrm{R}$ Srinivasan, Emerging Shifts in Learning Paradigms-From Millenials to the Digital Natives, 6.

${ }^{46}$ Darla Rothman, A tsunami og learners called Gen Z, Mdle, 4.
} 
berkembang dengan pesat. $^{47}$ Pembelajaran visual seperti melalui gambar, video games, dan video lebih menarik dan lebih efektif. ${ }^{48}$ Pembelajaran menggunakan media visual merupakan strategi pembelajaran yang paling efektif bagi anak-anak masa kini. $^{49}$ Pembelajaran yang menyenangkan adalah pembelajaran yang dimulai dengan penyampaian informasi yang disesuaikan dengan kebutuhan dan karakteristik anak. ${ }^{50}$

Ketiga, pembelajaran kinestetik. Pembelajaran kinestetik dengan bermain, menghadirkan kepada anak suatu pembelajaran yang disertai dengan banyak kegiatan. Anak-anak tidak hanya disuguhkan media-media visual saja namun juga disertai dengan permainan kontekstual, yang berhubungan dengan materi. Melalui bermain anak belajar dengan metode trial and error, saat mereka mengalami kegagalan mereka akan belajar dari kegagalan tersebut dan menggunakannya untuk mencapai tujuan mereka dalam permainan tersebut. $^{51}$ Permainan yang interaktif akan menolong anak untuk lebih mudah menerima materi yang disampaikan.

${ }^{47}$ Ibid. 3.

${ }^{48}$ Christine Chung, Dkk, "Teaching Generation $\mathrm{Z}$ at the University of Hawai", (Hawai: [t.p], 2016), 5.

${ }^{49}$ Abdul Khaliq Ramadlani Dan Marko Wibisono, Visual Literacy And Character Education For Alpha Generation, (Malang: Faculty Of Letters, Universitas Negeri Malang, 2017), 6-7.

${ }^{50}$ Fatemeh Talebzadeh dan Mahmoud Samkan, Happines for our kids in schools: A conseptual model, (Procedia - Social and Behavioral Sciences, 29, 2011),1462-1471.

${ }^{51}$ Yelana Thomas dan $\mathrm{R}$ Srinivasan. Emerging Shifts in Learning Paradigms-From Millenials to the Digital Natives, 7.
Keempat, anak-anak usia 5-6 tahun memerlukan tempat dan suasana belajar yang menyenangkan karena kinerja otak menjadi lebih baik dan meningkatkan produktivitas. ${ }^{52}$

\section{Khotbah Eksposisi Narasi Yang Kreatif Dan Kontekstual Kepada Anak-Anak Generasi Z Usia 5-6 Tahun}

Khotbah eksposisi narasi yang kreatif dan konstekstual memiliki 3 komponen utama, yaitu Pertama, pengkhotbah khotbah eksposisi narasi yang kreatif dan kontekstual kepada anak-anak generasi $\mathrm{Z}$ usia 5-6 tahun adalah pengkhotbah yang memiliki kualifikasi rohani sudah lahir baru. Artinya ia adalah orang yang sudah percaya dan memiliki iman kepada Tuhan Yesus. Penyebabnya adalah karena tidak mungkin jika seorang pengkhotbah yang mati rohani harus menuntun anak-anak yang mati rohani juga.

Pengkhotbah harus mengandalkan Roh Kudus, artinya pengkhotbah menyerahkan diri sepenuhnya untuk dipimpin oleh Roh Kudus dalam proses persiapan yang meliputi proses penafsiran induktif (Observasi, Interpretasi, Aplikasi) karena Roh Kuduslah yang akan bekerja menyingkapkan rahasia kebenaran dalam Alkitab kepada pengkhotbah. Selain itu, Roh Kudus juga merupakan oknum yang berperan untuk mengubahkan hidup anak-anak yang mendengarkan khotbah dari

${ }^{52}$ Ben-Shahar, T. Happier: Learn the Secrets to Daily Joy and Lasting Fulfillment. (USA: McGraw-Hill Companies, 2007), 5. 
manusia berdosa menjadi anak-anak Allah.

Standart kompetensi yang harus dimiliki oleh pengkhotbah adalah pengkhotbah memiliki pengetahuan Alkitab sehingga dapat menafsirkan Alkitab dengan tepat, benar dan kontekstual, dapat menghubungkan dan menjelaskan penyataan Allah dalam perikop yang khotbahkan. Beranjak dari konsep bahwa inti dari khotbah eksposisi narasi adalah pemberitaan kebenaran tentang Allah maka selain mengandalkan Roh Kudus pengkhotbah juga harus memiliki pengetahuan Alkitab yang memadai untuk melakukan proses penafsiran teks dan perumusan aplikasi khotbah. Hingga akhirnya pengkhotbah dapat merumuskan suatu amanat khotbah yang alkitabiah dan aplikatif.

Dari sudut pandang kepribadian, pengkhotbah adalah orang yang mengasihi anak-anak, memahami konteks anak-anak generasi $\mathrm{Z}$ usia 5-6 tahun dan menguasai teknologi. Atas dasar kasih, pengkhotbah akan rela untuk memberikan waktunya untuk berinteraksi dengan anak-anak yang dilayani, berusaha untuk memahami karakteristik dan kebutuhan dari anakanak yang dilayani yaitu anak-anak generasi $Z$ usia 5-6 tahun. Karakteristik dan kebutuhan utama dari generasi $\mathrm{Z}$ selain kebutuhan utama untuk selamat, yaitu karakteristik dan kebutuhan belajar dengan menggunakan teknologi, media visual, dan permainan interaktif.

Kedua, isi khotbah eksposisi narasi yang kreatif dan kontekstual kepada anak-anak generasi $\mathrm{Z}$ usia 5-6 tahun ialah alkitabiah yang artinya amanat khotbah berdasarkan pada amanat teks yang dirumuskan sesuai dengan konteks sejarah penulisan. Aplikatif dan relevan sesuai dengan konteks pendengar, tidak menimbulkan kerancuan dalam proses berfikir anak, berpusat kepada pemberitaan tentang Kristus, menyatakan kebenaran tentang berita keselamatan sehingga anak-anak dapat dibawa kepada pengenalan dan penerimaan secara pribadi terhadap Tuhan Yesus.

Ketiga, cara komunikasi khotbah eksposisi narasi yang kreatif dan kontekstual kepada anak-anak generasi $\mathrm{Z}$ usia 5-6 tahun. Kunci utama dalam cara komunikasi kepada anak-anak generasi Z usia 5-6 tahun adalah sesuai dengan kebutuhan dan karakteristik perkembangan mereka. Mempertimbangan pada setiap kajian teori pada bab 2 dan 3 serta hasil analisis yang telah dilakukan. Maka, cara komunikasi yang dapat digunakan untuk khotbah eksposisi narasi kepada anak-anak generasi Z usia 5-6 tahun di Sekolah Minggu adalah menggunakan teknik berkhotbah narasi dalam bentuk cerita, menggunakan media teknologi dan audiovisual untuk menarik minat anak-anak, serta kegiatan permainan interaktif dimana anak-anak terlibat secara langsung untuk mendalami Firman Tuhan yang disampaikan.

Teknik bercerita merupakan cara yang efektif untuk menanamkan nilainilai kebenaran dalam diri anak-anak. Pada usia ini, anak-anak sudah mampu untuk memahami cerita yang disampaikan oleh pengkhotbah. Dalam bercerita pengkhotbah harus 
menjelaskan dengan bahasa yang sederhana, suara dan gerak tubuh yang menarik dan disampaikan dengan berani dan percaya diri. Cerita juga dapat dikemas secara menarik sesuai dengan minat anak di bidang teknologi dan media audio visual. Penggunaan teknologi melalui media audio visual berupa film animasi dan slide dapat membantu pengkhotbah menyampaikan cerita secara lebih kreatif dan kontekstual.

Selanjutnya, penggunaan permainan interaktif. Mendasar pada kebutuhan akan teknologi dan tujuan utama dari khotbah eksposisi narasi ini adalah untuk membawa anak-anak kepada Yesus sampai mereka mau menerimaNya. Pengkhotbah dapat menggunakan permainan maze. Permainan maze atau yang dikenal dengan istilah labirin adalah sebuah permainan mencari jalan keluar dari jalan yang bercabang dan berliku. ${ }^{53}$ Permainan maze adalah permainan sejenis puzzle yang berbentuk alur atau jalur-jalur yang bercabangcabang dan berliku-liku yang bermanfaat untuk melatih konsentrasi, koordinasi tangan dan mata, dan melatih motorik halus. Pada permainan ini anak akan diajak untuk mencari satu jalan keluar. Prinsip ini dapat digunakan sebagai jembatan untuk mengkomunikasikan bahwa Tuhan Yesus adalah satusatunya jalan keselamatan. Permainan maze ini dapat dikemas dalam bentuk powerpoint, sehingga guru sekolah

\footnotetext{
${ }^{53}$ Kadek Suela, Permainan Maze Untuk Mereduksi Perilaku Self Stimulation Pada Anak Autis, (Surabaya: Unesa, 2015), 2-3
}

minggu juga dapat dengan mudah mempersiapkannya.

Terakhir, kegiatan interaktif yang melibatkan anak-anak ikut berperan didalamnya dan melakukan kegiatan seni bersama-sama. Mendasar pada perkembangan seni anak usai 5-6 tahun, kegiatan seni yang dapat digunakan untuk proses khotbah eksposisi narasi yang kreatif dan kontekstual adalah art performance. Seni yang dapat ditampilkan anak secara bersama-sama ialah pertama, memainkan alat perkusi dan bernyanyi bersama. Hal ini didasarkan pada perkembangan seni music anak usia 5-6 tahun, dimana mereka sudah dapat memainkan alat music dari benda disekitar dengan irama sambil bernyanyi.

Kedua, berdasarkan teori perkembangan kognitif dan bahasa, anak usia 5-6 tahun mengalami peningkatan pemahaman terhadap symbol dan gambar serta dari segi bahasa anak telah mampu mengungkapkan pendapatnya. Kegiatan seni yang dapat dilakukan adalah anak diberikan kegiatan menggambar dengan tema sesuai dengan khotbah eksposisi narasi yang disampaikan kemudian anak mempresentasikan hasil gambarannya.

Ketiga, berdasarkan teori perkembangan seni dan kognitif, anak usia 5-6 tahun memiliki daya imajinasi yang tinggi, kegiatan seni yang bisa dilakukan adalah bermain peran sesuai dengan khotbah eksposisi narasi yang disampaikan.

Berdasarkan pada teori generasi Z dan pengamatan terhadap anak-anak usia 5-6 tahun di Sekolah Minggu GBI 
Ngawi menunjukkan bahwa anak-anak usia 5-6 tahun saat ini adalah anak-anak yang paham teknologi. Mereka sangat antusias terhadap pembelajaran yang disampaikan dengan sentuhan teknologi. Kebutuhan pembelajaran mereka adalah pembelajaran yang menggunakan teknologi, media visual, dan permainan interaktif.

Keempat, pendengar khotbah eksposisi narasi yang kreatif dan kontekstual ini adalah anak-anak generasi $\mathrm{Z}$ usia 5-6 tahun, mendasar pada Kisah Para Rasul 6-7 dan Yohanes 6:1-13 sikap utama yang harus dimiliki oleh anak-anak agar hidupnya diubahkan oleh khotbah yang disampaikan adalah yang mau terbuka terhadap pemberitaan firman dengan mendengarkan khotbah tersebut dengan sungguh-sungguh.

\section{KESIMPULAN DAN SARAN}

Pada hakekatnya khotbah eksposisi narasi yang kreatif dan kontekstual kepada anak-anak generasi $\mathrm{Z}$ usia 5-6 tahun ini berpusat pada satu hal yaitu menghadirkan khotbah yang berpusat kepada Yesus Kristus untuk menyampaikan kebenaran kepada anakanak sehingga mereka dapat mengenal Tuhan dan menerima Tuhan Yesus secara pribadi.

Penulis memberi saran kepada para guru sekolah minggu di gerejagereja agar memanfaatkan model khotbah ini dalam pelayanannya. Selain itu agar semua guru sekolah minggu secara berkala mengevaluasi metode pelayanan yang digunakan dan mencari cara-cara kreatif dan kontekstual dalam pelayanannya kepada anak-anak sekolah minggu.

\section{DAFTAR PUSTAKA}

Abdul Khaliq Ramadlani, Khalig, Abdul dan Wibisono, Marko, Visual Literacy And Character Education For Alpha Generation, Malang: Faculty Of Letters, Universitas Negeri Malang, 2017

Ádám Nagy, Adam and Kölcsey, Attila, Generation Alpha: Marketing or Science?, Acta Technologica Dubnicae, vol. 7, issue 1, 2017

Chung, Christine, dkk, "Teaching Generation $\mathrm{Z}$ at the University of Hawai”, Hawai: [t.p], 2016

Desmita, Psikologi Perkembangan Anak, Bandung: PT Remaja Rosdakarya, 2010 Ginting, BR. "Peranan Guru Sekolah Minggu dalam Proses Pengajaran di Sekolah Minggu." UKSW, Salatiga, 2013.

Greidanus, Sidney. Preaching Christ from the old testament. Bandung: Kalam Hidup, 2009.

https: //en. wikipedia. org/wiki/Child_development, diakses 6 Februari 2019

Hulst, S. Mary, Pedoman Khotbah Lengkap, Jakarta: Waskita, 2018

L, Richard. Penginjilan di Sekolah Minggu. USA: The Gospel Publishing House, 1983.

Permendiknas tentang Pendidikan Anak Usia Dini, Nomor 137 tahun 2014

Rothman, Darla. "A Tsunami of learnes called Gen Z." Mdle , 2014: Vol 1, Issue 1.

Ruth Laufer, Anni Dyck. Pedoman Pelayanan Anak. Surabaya: Bahtera, 2014. 
"Seminar Pelatihan Superbook", Caruban,: 4 Mei 2018

Shahar, Ben, and Happier T, Learn the Secrets to Daily Joy and Lasting Fulfillment.USA: McGraw-Hill Companies, 2007

Shelly, A. Judith, Kebutuhan Rohani Anak, Bandung: Yayasan Kalam Hidup, 2003

Sidjabat, B.S. Membesarkan Anak Dengan Kreatif. Yogyakarta: Andi, 2012.

Slameto, Generation $Z$ and the Implication for Counseling, Salatiga: Universitas Satya Wacana Press, 2015 Solihin, Benny. 7 Langkah Khotbah yang Mengubah Kehidupan. Malang: Literatur SAAT, 2014.

Surya Putra S. Putra, Theoretical reviews: Teori Perbedaan Generasi, Jurnal Among Mikarti, Vol 9, No18, 2016

Suela, Kadek, Permainan Maze Untuk Mereduksi Perilaku Self Stimulation Pada Anak Autis, Surabaya: Unesa, 2015

Talebzadeh, Fatemah dan Mahmoud Samkan, Mahmoud, Happines for our kids in schools: A conseptual model, (Procedia - Social and Behavioral Sciences, 29, 2011),1462-1471. www.alkitab.sabda.org. www.superbookindonesia.com www. dpagbi. org/sites/index.php/beritautama/60-rakernas-i-2018/588-keputusan-rakernas-i-2018

www.biblestudytools.com/lexicons/greek/na s/paidion.html

Yelana ThomasYelana dan Srinivasan, R. Emerging Shifts in Learning Paradigms-From Millenials to the Digital Natives. International Journal of Applied Engineering Research, Vol 11, Num 5, 2016

Yuliati, T. Penginjilan Anak (Bahan Ajar), Surakarta: STT Gamaliel, 2014 